\title{
Free Cash Flow And Earnings Management: The Moderating Role Of Governance And Ownership
}

Mehdi Nekhili, University of Maine, GAINS-ARGUMANS, ICD International Business School, France Ines Fakhfakh Ben Amar, Institut Supérieur d'Administration des Affaires de Sfax, Tunisia

Tawhid Chtioui, ICD International Business School, France

Faten Lakhal, IRG, Université Paris-Est Créteil Val de Marne, France

\begin{abstract}
The purpose of this paper is to analyze the moderating effect of corporate governance and ownership features in lessening earnings management practices in a free cash flow (FCF) situation. A simultaneous equations model is developed to address endogeneity of the FCF variable. Based on a sample of French companies belonging to the SBF 120 index from 2001 to 2010, the results highlight the opportunistic behavior of managers in presence of free cash flows. Particularly, managers engage in earnings management practices that increase reported earnings. Our results also show that corporate governance mechanisms such as audit committee independence and external audit quality, in addition to institutional investors and managerial ownership reduce the extent of earnings management. Corporate governance mechanisms are substitutive in their monitoring role of managers' behavior to reduce earnings management in presence of a free cash flow problem.
\end{abstract}

\section{INTRODUCTION}

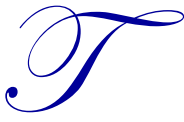

he concept of free cash flow ( $F C F$ from now on), introduced by Jensen (1986), refers to the sum of the surplus funds available after funding profitable projects. To describe a $F C F$ situation, the positive relation between abundance of cash flows and lack of good growth opportunities is often referred to Lehn and Poulsen (1989), Pindado and Miguel (2001) and Pindado and Torre (2009). Indeed, companies that have excess funds risk ending up wasting them in unprofitable projects (Jensen, 1986; Richardson, 2006). Subsequently, the existence of a substantial level of $F C F$ might lead managers to opt for sub-optimal investment policies. To conceal their projects counter-performance, managers may engage in aggressive earnings management practices (Chung et al., 2005a; Chung et al., 2005b; Jaggi and Gul, 2006; Bukit and Iskandar, 2009; Rusmin et al., 2014). Two situations described in the literature are possible. The first one occurs when managers manipulate their earnings upwardly to conceal counter-performance (Chung et al., 2005a; Jaggi and Gul, 2006; Rusmin et al., 2014). The second situation arises when managers opt for downward earnings management to smooth earnings in the following years, when the negative impact of sub-optimal investment begins to appear (Chung et al., 2005b).

The aim of our study is twofold. Firstly, it examines the relation between $F C F$ level and earnings management. Secondly, it examines the impact of ownership and governance features on managers' propensity to use earnings management in a $F C F$ situation. The French context is worthy to study managers' propensity to use earnings management in a particular FCF situation. Dittmar et al. (2003) show that companies in countries with weak investor protection, such as France, hold on average more liquid assets than those set up in common law countries. Dittmar et al. (2003) show, moreover, that in civil law countries, shareholders face greater difficulties in constraining managers' behavior when it comes to distributing available cash. Henceforth, the propensity to manage earnings is stronger in countries with weak protection of minority stock-owners to conceal discretionary use of available funds and extraction of private benefits (Leuz et al., 2003). In this regard, it is worthwhile to mention that French firms display important cash resources equal to 9.6\% of total assets during 1981-2008 (Iskandar-Datta and Jia, 2012). 
Managers' behavior is dependent on the ownership and corporate governance characteristics that can determine their margin of discretion and thus guide surplus funds use. These features should become all the more influential when minority holders' legal protection is not guaranteed. They can directly impact managers' propensity to manage earnings; or indirectly by reducing the $F C F$ level. As governance characteristics, we select: the board's size and degree of independence; duality of CEO and chairman of the board; the presence of an audit committee and its degree of independence; and audit by "big" auditors. Regarding ownership characteristics, our variables relate to the percentage of equity held by the reference shareholder (individual or represented by a family), institutional ownership, managerial ownership, and finally the share of capital held by independent directors. To test our hypotheses, we chose to apply the simultaneous equations model that explains both the direct and indirect effects (through impact on $F C F$ ) of ownership and governance characteristics on managers' propensity to manipulating earnings.

To the best of our knowledge, this is the first paper to systematically test the relationship between $F C F$ and earning management practices in the French context. It also examines the moderating effect of corporate governance and ownership structure on this relationship. Results obtained on a sample of French SBF 120 companies from 2001 to 2010 highlight managers' opportunistic behavior, which results in upward earnings management increasing in a $F C F$ situation. They also show that managers' propensity to manage earnings in a $F C F$ situation is dependent on the presence and effectiveness of particular governance mechanisms and ownership characteristics. Particularly, audit committee independence and external audit quality, in addition to ownership structure features such as institutional investors and managerial ownership reduce the extent of earnings management in a free cash flow situation. However, board independence and independent directors' ownership has no significant impact on earnings management. These findings suggest that corporate governance mechanisms are substitutive in their monitoring role of managers' behavior to reduce earnings management in presence of a free cash flow problem.

Our paper is organized as follows: in the first section, we present the theoretical framework and hypotheses. The second section focuses on methodological aspects followed by results and discussion. The final section concludes the paper.

\section{THEORETICAL FRAMEWORK AND HYPOTHESES}

\subsection{FCF and Earnings Management}

One source of conflict of interest between shareholders and managers is the presence of cash available after all profitable projects has been financed, and that have not been distributed as dividends or super-dividends. Jensen (1986) describes this as a FCF situation. The emphasis is on managers' misuse of these funds, i.e., whose allocation has nothing to do with the company's interests. Based on the investment opportunities that arise, shareholders may describe a $F C F$ situation as worrying or not. Indeed, in companies with good growth opportunities, agency costs related to the $F C F$ problem are not significant enough (McConnell and Servaes, 1995; Alonso et al., 2005; Lasfer, 2006; Gregory and Wang, 2013).

Conversely, in the absence of good growth opportunities, an overinvestment problem is likely to arise, which is detrimental to shareholders (minority ones, at least). This situation is explained by leaders' willingness to inexorably promote company growth to increase its size and, de facto, their level of compensation (Jensen and Murphy, 1990) and discretion (Stulz, 1990). A $F C F$ situation can also lead the company to repurchase its own shares as well as carry out related parties transactions (with leaders, major shareholders and/or directors), full-fledged means of extracting private benefits and expropriating minority shareholders (Nekhili and Cherif, 2011). Such behavior may adversely affect the company's financial position, lead to lower stock prices and possibly cause managers to be replaced (Opler et al., 2001; Richardson, 2006). To reduce its impact, the latter might manipulate earnings to conceal their use of available discretionary funds and facilitate the extraction of private benefits of control (Leuz et al., 2003).

Jaggi and Gul (2006) show a positive relation between $F C F$ and earnings management. These authors state that managers in companies with high $F C F$ indulge in manipulating earnings upward to post (actually not so) good performances and safeguard job security. These results are confirmed by Chung et al. (2005a), who argue that 
companies with a high $F C F$ level use earnings enhancing discretionary accruals ${ }^{1}$ to cover up negative NPV projects. This result is confirmed by Bukit and Iskandar (2009). Based on a sample of 155 companies listed on the Malaysian Stock Exchange in 2001, the authors find that earnings management can be more readily feasible in companies with high FCF levels. More recently, Rusmin et al. (2014) argue that the relationship between FCF and incomeincreasing accounting choice is not systematic and depends on specific feature of the institutional environment. The authors document a positive relationship between $F C F$ and income-increasing accounting choice in Malaysia, and this relationship is partially applicable in Singapore but it is not valid in Indonesia.

However, Chung et al. (2005b) argue that a $F C F$ situation gives evidence on motivations for downward earnings management. They find that companies with high $F C F$ and low growth opportunities use discretionary accruals to downgrade their earnings levels. According to these authors, a high $F C F$ situation and low growth opportunities are bound to result in low long term profitability. To conceal the impending bad performance of these new investments, corporate executives turn to negative accruals to reduce current year's earnings and smooth earnings when the negative effect of these investments occurs. Taken together, these arguments lead to our first hypothesis:

H1: Earnings management increases with the level of $F C F$.

\subsection{The Moderating Role of Governance}

\subsubsection{The Role of the Board of Directors}

The board of directors is the central body responsible for company's good governance, hence for the reliability of the financial information provided to business partners. However, the board's effectiveness in its oversight depends on various characteristics. Though a large board can boast being richer in experience and expertise, these benefits might be wiped out by the difficulty of coordinating individual contributions, conflicts during decision-making and high communication costs (Jensen and Meckling, 1976). The presence of independent directors also endows the board with greater expertise and independence from the management team, thereby strengthening its resistance to potential waste of funds. Richardson (2006) argues that outside directors are able to identify overinvestment situations and may oppose any abuse in available funds use. The author shows that the overinvestment issue is not so acute when $F C F$ occurs in companies whose boards enjoy a greater degree of independence. As for Lasfer (2006), he finds that a high proportion of outside directors limit $F C F$-induced agency costs, while it positively and significantly affects the performance of companies with low growth opportunities. Using a sample of 597 French listed firms during 2001-2007, Boubaker et al. (2013) find that is those appointing independent directors, accumulate less cash reserves than those with less effective boards.

In view of the relation alleged in our first hypothesis between $F C F$ and accruals levels, we should expect, in a $F C F$ situation, a positive relation between board-size and discretionary accruals levels, and another, negative one, between board independence and earnings management. Then, we formulate the two following hypotheses:

H2a: There is a positive relation between board-size and earnings management in a $F C F$ situation.

H2b: There is a negative relation between board independence and earnings management in a $F C F$ situation.

\subsubsection{CEO Duality}

CEO duality refers to a board leadership structure in which the CEO is the chairman of the board positions. It enables the CEO to affect the board's disciplinary role (Lipton and Lorsch, 1992). Indeed, given his dual role in the board, the CEO may become more entrenched through launching projects that are mainly dependent on his own human capital. To ensure the effectiveness of the board in monitoring the use of cash flows, Jensen (1986) recommends separating these two positions. In this regard, Lasfer (2006) shows that, in the British context, such

\footnotetext{
${ }^{1}$ Accruals consist of "all income and expenses recorded in the income statement that have not led to any flow during the fiscal year. These are the calculated expenses and revenue (amortization, depreciation and reversals...) and lagged expenses and revenue (constituent parts of the net change in working capital). Some of these adjustments, non-discretionary ones, result from normal business activity. Discretionary ones are managed intentionally by corporate executives and are used to detect earnings management.
} 
position separation positively affects the performance of companies with low growth opportunities and hence limits the $F C F$-related agency costs. Similarly, several studies document a positive relation between cumulating these two functions and the production of financial statements that do not conform to generally accepted accounting principles (Beasley, 1996; Dechow et al., 1996; Peasnell et al., 2005). We therefore develop our third hypothesis as follows:

H3: There is a positive relation between CEO duality and earnings management in a $F C F$ situation.

\subsubsection{The Role of the Audit Committee}

The Audit Committee is a central body meant to keep up investors' trust and interests by performing a number of functions. Here are the most important ones: reviewing the adequacy of internal controls; monitoring the financial reporting process; reviewing external audit functions and selecting and monitoring external auditors. The existence of an audit committee may be considered as a quality indicator of the board of directors' control. A growing body of research shows the inhibitory effect of the committee's independence on the magnitude of discretionary accruals. Dechow et al. (1996) argue that accounting manipulations are more frequent in companies with no audit committee. In the French context, Piot and Janin (2007) find that companies with an audit committee post fewer abnormal accruals suggesting the importance of such a body in improving the auditing process in general and limiting the use of accounting manipulations in particular.

It is in a special $F C F$ situation that the Audit committee's degree of independence is an even more discriminating factor (Bukit and Iskandar, 2009). Using a sample of 155 companies listed on the Malaysian stock exchange in 2001, the authors explain that an independent audit committee can limit earnings management practices, primarily in companies with $F C F$ surplus. These analyses lead us to formulate two hypotheses:

H4a: There is a negative relation between the presence of an audit committee and earnings management results in a FCF situation.

H4b: There is a negative relation between the audit committee's independence and earnings management in a $F C F$ situation.

\subsubsection{Audit Quality}

The demand for quality accounting information is a fundamental aspect of corporate governance. It is generally accepted that the major audit firms, including the "Big 4" make for better verification of financial statements accuracy and consistency (DeAngelo, 1981). Accordingly, Chung et al. (2005a) found that "Big" auditors limit the use of discretionary accruals, but are especially more active when client companies have a high $F C F$ level. This result is confirmed by Rusmin et al. (2014) in the Malaysian case. In such a situation, auditors become more vigilant and limit the use of discretionary accruals designed to increase earnings. However, the French context looks as if it has particular features likely to reverse the observed trend in the research conducted in the U.S. Indeed, Piot and Janin (2007) find no significant relation between the presence of a "Big" auditor in the College of Auditors and the level of abnormal accruals. According to these authors, this might be due to the French legal setting: it limits French auditors' responsibility much more than American ones'. In addition, Piot and Janin (2007) argue that using higher quality auditing results in greater reliability than greater accuracy of accounting figures. Francis et al. (2009) go even further and stipulate that companies that publish relatively high levels of discretionary accruals are those that rely more on "Big" auditors -to bring some credibility to the accounting figures disclosed to the market. We thus develop the following hypothesis:

H5: There is a negative relation between the use of "Big 4" auditors and earnings management in a $F C F$ situation. 


\subsection{The Moderating Role of the Ownership Structure}

\subsubsection{Presence of a Reference Shareholder}

Shareholders holding a significant stake may find it interesting to ensure strict control over managers since these will appropriate a significant proportion of the additional profits conjured up that way. These shareholders can, on the one hand, more easily mobilize significant resources to protect their investments. On the other hand, the number of votes they have enables them to impact voting at general meetings or possibly convince small shareholders to support their decisions. Regarding reference shareholders' ability to limit the FCF problem, Alonso et al. (2005) find that their presence positively and significantly affects the financial performance of companies with low growth opportunities. They are also able to limit managers' discretion in earnings management (Dechow et al., 1996). In a multi-country design, Attig et al. (2013) also show that the presence of multiple large shareholders improves internal monitoring and shrinks the agency costs of companies' cash holding. Our sixth hypothesis is then as follows:

H6: There is a negative relation between the percentage of voting rights held by the reference shareholder and earnings management in a $F C F$ situation.

\subsubsection{Institutional Ownership}

Because of their financial and technical abilities, institutional investors allocate significant funds in corporate control and rely on financial experts to better measure the value of the investments their managers suggest (Jensen and Meckling, 1976). Indeed, institutional investors can detect a $F C F$ problem and thus remedy it by prohibiting unprofitable investments and demanding available funds be distributed to shareholders. Henceforth, institutional ownership may actually protect the interests of shareholders and mitigate agency problems (Gregory and Wang, 2013). The presence of an institutional investor holding a large share of capital prevents managers from behaving in an opportunistic manner and can therefore restrict aggressive earnings management. Chung et al. (2005a) show that institutional investors demonstrate their activism by reducing aggressive earnings management in a $F C F$ situation. These arguments lead to the following hypothesis:

H7: There is a negative relation between the percentage of shares held by institutional investors and earnings management in a $F C F$ situation.

\subsubsection{Managerial Ownership}

Managerial ownership is a mechanism to align corporate executives' interests with shareholders' ones (Jensen and Meckling, 1976). When managers hold a high number of shares, they are less likely to maximize their personal wealth through opportunistic behavior, since they might well suffer the consequences. Therefore, such participation ensures better use of available surplus cash flows. Jensen $(1986,1989)$ emphasizes the role of managerial ownership in reducing risks related to excess cash flow. Agrawal and Jayaraman (1994) find that $F C F$-induced agency costs are a decreasing function of managerial ownership. Meanwhile, McConnell and Servaes (1995) show that the relation between managerial ownership and firm value is higher in companies with both low growth opportunities and potential risk of $F C F$. In the French context, these results are confirmed by Nekhili et al. (2009) who find a significant negative relation between the percentage of capital held by managers and $F C F$ level. Furthermore, Warfield et al. (1995) show that management participation in the capital reduces (consistently with the theory of convergence of interests) managers' propensity to use discretionary earnings manipulation. We then test the following hypothesis:

H8: There is a negative relation between the percentage of capital held by executives and management earnings in a FCF situation.

\subsubsection{Independent Director Ownership}

The percentage of capital held by independent directors highlights their incentives, as shareholders, to effectively perform their duties as controllers. Indeed, external directors' participation in company share capital encourages 
them to control executives' behavior and oppose their decisions. These directors are seeking payment of surplus cash flow as dividends. Studies by Dechow et al. (1996) and Beasley (1996) confirm the negative relation between the proportion of shares held by external directors and the transgression of generally accepted accounting principles. In the French context, Nekhili et al. (2009) find a negative relation between the percentage of equity held by nonexecutive directors and $F C F$ level. These arguments lead to formulate our last hypothesis:

H9: There is a negative relation between independent directors' ownership and earnings management in a $F C F$ situation.

\section{METHODS}

\subsection{Sample}

Our initial sample consists of all companies belonging to the SBF 120 index over the 2001 to 2010 period. From this sample, we eliminated financial, real estate, insurance companies, as well as companies with missing data or outliers. This selection procedure has resulted in an unbalanced sample of 789 observations about 85 companies from 2001 to 2010. Accounting and financial informations are available in the Worldscope database. Data on ownership structure and board characteristics were hand-collected from annual reports and reference documents which are obtained from the database of the AMF (Autorité des Marché Financiers) and from companies' websites.

\subsection{Definition and Measurement of Variables}

\subsubsection{Measuring earnings management - Discretionary accruals (DAC)}

We propose to estimate discretionary accruals through the model of Kothari et al. (2005), as follows:

$$
\mathrm{TA}_{\mathrm{i}, \mathrm{t}} / \mathrm{A}_{\mathrm{i}, \mathrm{t}-1} \mid=\mathrm{a}_{0}\left(1 / \mathrm{A}_{\mathrm{i}, \mathrm{t}-1}\right)+\mathrm{a}_{1}\left[\left(\Delta \mathrm{CA}_{\mathrm{i}, \mathrm{t}}-\Delta \mathrm{CCR}_{\mathrm{i}, \mathrm{t}}\right) / \mathrm{A}_{\mathrm{i}, \mathrm{t}-1}\right]+\mathrm{a}_{2}\left(\mathrm{PPE}_{\mathrm{i}, \mathrm{t}} / \mathrm{A}_{\mathrm{i}, \mathrm{t}-1}\right)+\mathrm{a}_{3}\left(\mathrm{ROA}_{\mathrm{i}, \mathrm{t}-1}\right)+\varepsilon_{\mathrm{i}, \mathrm{t}}
$$

with:

$$
\begin{array}{ll}
T A_{\mathrm{i}, \mathrm{t}} & : \text { Total accruals of firm } \mathrm{i} \text { in year } \mathrm{t} \text { measured as follows: } \\
& \mathrm{TA}_{\mathrm{i}, \mathrm{t}}=\text { Total net income }- \text { Cash flow from operations; } \\
A_{i, t-1} & : \text { Total assets at the beginning of the period of firm } \mathrm{i} ; \\
\Delta C A_{i, t} & : \text { Change in sales between year } \mathrm{t} \text { and year } \mathrm{t}-1 \text { of firm } \mathrm{i} ; \\
\Delta C C R_{i, t} & : \text { Change in receivables between year } \mathrm{t} \text { and } \mathrm{t}-1 \text { of firm } \mathrm{i} ; \\
P P E_{i, t} & : \text { Gross value of fixed assets in year } \mathrm{t} \text { of firm } \mathrm{i} ; \\
R O A_{i, t-1} & : \text { Ratio of net income of firm i to total assets at the beginning of the period. }
\end{array}
$$

All variables in the model are standardized by total assets $(\mathrm{t}-1)$ to reduce the problem of heteroscedasticity. In our estimation of accruals, we follow Hribar and Collins's (2002) approach. Non-discretionary accruals (NDACi,t) are obtained using the following earnings management model:

$$
\operatorname{NDAC}_{\mathrm{i}, \mathrm{t}} / \mathrm{A}_{\mathrm{i}, \mathrm{t}-1}=\hat{\mathrm{a}}_{0}\left(1 / \mathrm{A}_{\mathrm{i}, \mathrm{t}-1}\right)+\hat{\mathrm{a}}_{1}\left[\left(\Delta \mathrm{CA}_{\mathrm{i}, \mathrm{t}}-\Delta \mathrm{CCR}_{\mathrm{i}, \mathrm{t}}\right) / \mathrm{A}_{\mathrm{i}, \mathrm{t}-1}\right]+\hat{\mathrm{a}}_{2}\left(\mathrm{PPE}_{\mathrm{i}, \mathrm{t}} / \mathrm{A}_{\mathrm{i}, \mathrm{t}-1}\right)+\hat{\mathrm{a}}_{3}\left(\mathrm{ROA}_{\mathrm{i}, \mathrm{t}-1}\right)
$$

Discretionary accruals $\left(D A C_{i, t}\right)$ of firm $\mathrm{i}$ in year $\mathrm{t}$ are obtained by the difference between total accruals $\left(T A_{i, t}\right)$ and non-discretionary accruals $\left(N D A C_{i, t}\right)$.

$$
\operatorname{DAC}_{\mathrm{i}, \mathrm{t}}=\mathrm{TA}_{\mathrm{it}} / \mathrm{A}_{\mathrm{i}, \mathrm{t}-1}-\left[\hat{\mathrm{a}}_{0}\left(1 / \mathrm{A}_{\mathrm{i}, \mathrm{t}-1}\right)+\hat{\mathrm{a}}_{1}\left[\left(\Delta \mathrm{CA}_{\mathrm{i}, \mathrm{t}}-\Delta \mathrm{CCR}_{\mathrm{i}, \mathrm{t}}\right) / \mathrm{A}_{\mathrm{i}, \mathrm{t}-1}\right]+\hat{\mathrm{a}}_{2}\left(\mathrm{PPE}_{\mathrm{i}, \mathrm{t}} / \mathrm{A}_{\mathrm{i}, \mathrm{t}-1}\right)+\hat{\mathrm{a}}_{3}\left(\mathrm{ROA}_{\mathrm{i}, \mathrm{t}-1}\right)\right]
$$

To identify the direction of earnings management, we proceeded to the classification of observations according to the sign and magnitude of discretionary accruals over our studied period (2001-2010). The overall sample is divided into three sub-samples based on different levels of discretionary accruals. As Kothari et al. (2005), we use the upper quartile of discretionary accruals with the highest positive accruals to obtain the DAC_UP subsample and the lower 
quartile of discretionary accruals with the highest negative discretionary accruals to form the DAC_DOW subsample. For the $D A C_{-} M O D$ subsample, we select companies with low-level positive and negative discretionary accruals belonging to the median quartile values.

\subsubsection{Measuring FCF Level}

Following Miguel and Pindado (2001) and Pindado and De la Torre (2009), we measure the level of $F C F$ by multiplying the retained cash flow $(C F)$ by the inverse of Tobin's q. ${ }^{2}$ The greater the $C F$ and the lower the Tobin's q, the higher the $F C F$ risk. To compute $\mathrm{CF}$, we use the measure of undistributed cash flow: $[C F=$ operating income before depreciation - taxes - interest expense on borrowings - dividends on ordinary and preferred shares]. The cash flow is standardized by the book value of total assets.

\subsubsection{Control Variables}

Debt ratio (DEBT): From an agency point of view, debt is one means to discipline managers (Jensen, 1986; Lehn and Poulsen, 1989; Denis and Denis, 1995; Lang et al., 1996). In a FCF situation, Jelinek (2007) shows that an increase in debt reduces earnings management. We measure debt by the ratio of debt to total assets.

Dividend yield (DIV): Several authors, such as Lang and Litzenberger (1989), Smith and Watts (1992) and Gugler (2003), confirm the role of dividend policy in solving the FCF problem.

In a free cash flow situation, using excess resources to pay dividends can help to avoid overinvestment in inappropriate projects (Cheng et al., 2014). We measure dividend yield by the ratio of dividend to share price.

Listing in the United States (CROSS LIST): The power of the U.S. stock market authority covers fields beyond market regulators' controls in many European countries, in particular regarding disclosure by companies, and accounting or control standards of the auditing profession (Klapper and Love, 2004). Ensuring better disclosure policy, listing in the United States is likely to limit earnings management practices and make extracting private benefits of control more costly and difficult to achieve (Doidge et al., 2004). Francis and Wang (2008) hence, show that accounting results are more cautious when investor protection is ensured. CROSS_LIST variable is a dichotomous variable equal to 1 if the company is listed on the U.S. market and 0 otherwise.

Return on assets (ROA): Increased performance naturally leads to an increase in cash flow, and a growing dividend distribution. Firm accounting performance is measured by return on assets, which is calculated by the ratio of net economic earnings to total assets.

Firm size (SIZE): Considering the size of the company as an indicator of political visibility, several researchers have concluded that large companies prefer accounting methods that reduce the result. Jaggi and Gul (1999) empirically documents that the conflict between managers and shareholders concerning free cash flow is more severe in large firms. Size is measured by the natural logarithm of total assets.

IFRS (IFRS): The adoption of IFRS should provide an environment conducive to better disclosure of accounting results. However, Jeanjean and Stolowy (2008) find that, though propensity to manipulate earnings has not really dropped in Australia and Britain, it has rather showed an upward trend after the implementation of these standards in France since 2005. These results imply, according to the authors, the primacy of national institutional rules and managerial incentives on accounting standards for resolving conflicts of interest between managers and shareholders. The IFRS variable is a binary variable taking the value 0 for the years from 2001 to 2004 and 1 from 2005 to 2010 .

Industry (INDUSTRY): The elements included in the calculation of accruals can vary from one sector to another. Since we do not have a sufficient number of companies by sector, an issue also raised by Francis et al. (2009, p. 58),

\footnotetext{
${ }^{2}$ Growth opportunities are measured by Tobin's q. This measure, defined as the ratio between the market value of the company and its replacement value, has the advantage of understanding the anticipated risk of FCF.
} 
we cannot compare our results according to their business sector. We therefore chose to introduce for each segment a binary variable taking the value 1 if the firm belongs to the sector in question and 0 otherwise. Sampled companies are distributed in accordance with the new sector classification adopted by Euronext namely the international Industry Classification Benchmark nomenclature (ICB). Our sample is mainly composed of industrial companies (28.17\%), followed by consumer goods companies (21\%), of companies in the technology sector $(18.43 \%)$ and companies specializing in consumer services $(11.05 \%)$.

\subsection{Descriptive Statistics and Correlations}

Table 1 reports the descriptive statistics for selected variables. In our sample, average free cash flow level (measured by retained cash flow divided by Tobin's q) includes $12.17 \%$ of net assets. This also means that our sampled firms generate a positive cash flow from their operating activities. Sampled companies have a board of directors (BOARD_SIZE) with around 10 members in average, of whom $40.98 \%$ are independent (BOARD_SIZE). We notice, however, a great disparity between companies with a percentage of independent members ranging from zero to $100 \%$. On average, the CEO is also the chair of the board of directors in $67.61 \%$ of cases. The transposition into French law of the $8^{\text {th }}$ European Directive leads to mandatory audit committee since 2008 only and imposes few constraints on the independence of members. Over the 2001 to 2010 period, $78.56 \%$ of sampled companies have an audit committee and their average independence (AUDCOM_IND) is relatively low (41.30\%). We also see that the average number of "Big" firms in the college of auditors is more than one (1.14). The reference shareholder (REF_SHARE) holds, on average, $33.51 \%$ of voting rights ranging from zero as minimum to $91.84 \%$. This finding is not surprising, given that French companies are characterized by the presence of controlling shareholders, advocating less separation between management and control functions (Boubaker et al., 2013). The average ratios of institutional ownership $\left(I N S T \_O W N\right)$, managerial ownership $\left(M A N_{-} O W N\right)$, and independent director ownership $\left(I N D \_O W N\right)$ are $13.88 \%, 19.04 \%$, and $3.42 \%$ respectively. Table 1 reports that $18.77 \%$ of sampled companies are cross-listed in the U.S. stock market. As for other characteristics, they have a low return on assets (4.04\%). Their dividend yield is equal to $2.78 \%$ and their debt ratio is $24.32 \%$ on average.

Table 1. Descriptive statistics

\begin{tabular}{lcccc}
\hline \multicolumn{1}{c}{ Variable } & Mean & Standard Deviation & Minimum & Maximum \\
\hline DAC & 0.04 & 0.16 & -1.55 & 0.74 \\
$F C F$ & $12.17 \%$ & $15.08 \%$ & 0 & $189.69 \%$ \\
BOARD_SIZE & 10.39 & 4.04 & 3 & 23 \\
BOARD_IND & $40.98 \%$ & $25.51 \%$ & 0 & $100 \%$ \\
DUAL & $67.61 \%$ & $49.44 \%$ & 0 & 1 \\
AUDCOM & $78.56 \%$ & $41.06 \%$ & 0 & 1 \\
AUDCOM_IND & $41.30 \%$ & $39.03 \%$ & 0 & $100 \%$ \\
BIG & 1.14 & 0.68 & 0 & 2 \\
REF_SHARE & $33.51 \%$ & $24.79 \%$ & 0 & $91.84 \%$ \\
INST_OWN & $13.88 \%$ & $21.77 \%$ & 0 & $90.12 \%$ \\
MAN_OWN & $19.04 \%$ & $18.55 \%$ & 0 & $80.01 \%$ \\
IND_OWN & $3.42 \%$ & $6.91 \%$ & 0 & $12.51 \%$ \\
DEBT & $24.32 \%$ & $14.50 \%$ & 0 & $83.72 \%$ \\
DIV & $2.78 \%$ & $4.98 \%$ & 0 & $38.20 \%$ \\
CROSS_LIST & $18.77 \%$ & $39.07 \%$ & $-15.90 \%$ & 1 \\
ROA & $4.04 \%$ & $5.49 \%$ & 9.32 & $28.5 \%$ \\
SIZE & 14.59 & 2.20 & & 19.03 \\
\hline All & & & 0 \\
\hline
\end{tabular}

All the financial variables are winsorized at the 1 and $99 \%$ levels.

Untabulated pairwise correlation matrix shows a higher correlation $(0.745)$ between the size of the board (BOARD_SIZE) and firm size (SIZE) indicating information redundancy between these two explanatory variables. Given the presence of significant correlations at $1 \%$ level between different independent variables, the variance inflation factors (VIF) are also computed to check for possible multicollinearity issues. In practice, a VIF value of 2 or 3 is proved to be a very thorough limit. For others variables, these scores range from 1.07 to 2.45 , indicating that multicollinearity has little impact on our analyses and the model variables contain complementary information. In 
order to focus on marginal contribution of firm size, we decide to change the size of the firm, mainly correlated with the board, using the proposed approach by Bradbury $(1990, \text { p. } 28)^{3}{ }^{3}$

\subsection{Model Specification}

Our purpose is to study the relation between $F C F$ and earnings management. The $F C F$ problem and the issue of earnings management may be affected by ownership and corporate governance characteristics. This dual status of the " $F C F$ " variable causes a bias in the coefficient estimates when we use the method of ordinary least squares (OLS) equation by equation. Therefore, it is interesting to test the endogeneity of the $F C F$ variable. Furthermore, the ownership and governance features can act directly on executives' attitude of using earnings performance $(D A C)$ or indirectly through their impact on $F C F$ levels. Our model then takes into account the direct effect of all mechanisms of corporate governance and ownership structure on earnings management and the indirect effect of these characteristics through $F C F$ levels. A simultaneous equations model is then developed to address these endogeneity problems. We then perform the Hausman test to determine which the most appropriate estimation method between $2 S L S$ and $3 S L S$ is. The Hausman test indicates that the $3 S L S$ estimate is better specified. Unlike the method of two stages least squares $(2 S L S), 3 S L S$ method takes into account the dependence between the error terms and can estimate both equations simultaneously.

This system contains two endogenous variables, namely $D A C$ and $F C F$, and is as follows: ${ }^{4}$

$$
\begin{aligned}
& D A C_{\mathrm{i}, \mathrm{t}}=\alpha_{0}+\alpha_{1} F C F_{\mathrm{i}, \mathrm{t}}+\alpha_{2} \text { BOARD_SIZE } E_{\mathrm{i}, \mathrm{t}}+\alpha_{3} \text { BOARD_IND } D_{\mathrm{i}, \mathrm{t}}+\alpha_{4} D U A L_{\mathrm{i}, \mathrm{t}}+\alpha_{5} \text { AUDCOM }_{\mathrm{i}, \mathrm{t}}+\alpha_{6} \\
& A U D C O M_{-} I N D_{\mathrm{i}, \mathrm{t}}+\alpha_{7} R E F \_S H A R E_{\mathrm{i}, \mathrm{t}}+\bar{\alpha}_{8} I N S T \_O W N_{\mathrm{i}, \mathrm{t}}+\alpha_{9} \bar{M} A N_{-} O W N_{\mathrm{i}, \mathrm{t}}+\alpha_{10} I N D \_O W N_{\mathrm{i}, \mathrm{t}}+\alpha_{11} B I G_{\mathrm{i}, \mathrm{t}}+ \\
& \alpha_{12} D E B T_{\mathrm{i}, \mathrm{t}}+\alpha_{13} \text { CROSS_LIST } T_{\mathrm{i}, \mathrm{t}}+\alpha_{14} \text { SIZE_RESID }_{\mathrm{it}}+\alpha_{15} \text { IFRS }_{\mathrm{i}, \mathrm{t}}+\alpha_{16}{ }_{1 N} \text { INDUSTRY_FE }+\alpha_{17} \text { YEAR_FE }+\varepsilon_{1 \mathrm{it}} \\
& F C F_{\mathrm{i}, \mathrm{t}}=\beta_{0}+\beta_{1} \text { BOARD_SIZE } \mathrm{i}_{\mathrm{i}, \mathrm{t}}+\beta_{2} \text { BOARD_IND } D_{\mathrm{i}, \mathrm{t}}+\beta_{3} D U A L_{\mathrm{i}, \mathrm{t}}+\beta_{4} A U D C O M_{\mathrm{i}, \mathrm{t}}+\beta_{5} \text { AUDCOM_IND } D_{\mathrm{i}, \mathrm{t}} \\
& +\beta_{6} \text { REF_SHARE }_{\mathrm{i}, \mathrm{t}}+\beta_{7} \mathrm{INST}_{-} \mathrm{OWN} \mathrm{N}_{\mathrm{i}, \mathrm{t}}+\beta_{8} M \bar{A} N_{-} O W N_{\mathrm{i}, \mathrm{t}}+\beta_{9} I N D \_O W N_{\mathrm{i}, \mathrm{t}}+\beta_{10} D E B T_{\mathrm{i}, \mathrm{t}}+\beta_{11} D I V_{\mathrm{i}, \mathrm{t}}+\beta_{12} \\
& R O A_{\mathrm{i}, \mathrm{t}}+\bar{\beta}_{13} S I Z E_{-} R E S I D_{\mathrm{i}, \mathrm{t}}+\beta_{14} I F R S_{\mathrm{i}, \mathrm{t}}+\beta_{15} I N D U \bar{S} T R Y_{-} F E+\beta_{17} Y E A R_{-} F E+\varepsilon_{2 \mathrm{it}}
\end{aligned}
$$

\section{RESULTS ANALYSIS}

Table 2 shows the results of the simultaneous equation model estimated by the $3 S L S$ method, for the overall sample and for the three sub-samples of companies: those that manage their earnings upwards $\left(A C D_{-} U P\right)$, those that manage their earnings downward $\left(A C D \_D O W\right)$ and those that manage their earnings in a moderate way $\left(A C D \_M O D\right)$. To confirm or reject our assumptions about the impact of $F C F(\mathrm{H} 1)$ as well as the characteristics of governance ( $\mathrm{H} 2$ to $\mathrm{H} 5)$ and ownership structure (H6 to H9) on the level of discretionary accruals, we discuss the results of the first equation of our model; the results for the second equation are presented to evaluate the $F C F$ situation endogenously.

For all the sampled companies, we find that the " $F C F$ " variable positively and significantly affects, at the $1 \%$ level, discretionary accruals. Our first hypothesis that companies with high $F C F$ s are most likely to manage their earnings is then corroborated. We also find, for the sample of companies that manage their earnings upwards, that the impact of $F C F$ is positive and significant at the $5 \%$ level on earnings management. However, the coefficient of the " $F C F$ " variable is negative and relatively low $(-0.077)$ for companies that manage their earnings moderately. It is also not significant for companies that manage their earnings downwards. These results show that companies with surplus $F C F$ use discretionary accruals to manage their earnings mainly upwards. Indeed, an increase in earnings announced

\footnotetext{
${ }^{3}$ According to Bradbury (1990), the problem of correlation between the various measures of the "size" can be solved by holding the residual contribution of firm size (orthogonal) on the governance bodies (board of directors in our case). In order to estimate the residual contribution of the size of the firm, we begin by estimating the following regression: SIZE $=\alpha_{0}+\alpha_{1} B O A R D \_S I Z E+\varepsilon$

This regression provided values of 10.565 and 0.395 for $\alpha_{0}$ and $\alpha_{1}$, respectively. Both estimators were significant at $1 \%$ level. The coefficient of determination is $54.13 \%$ and the $\mathrm{F}$ statistic is 953.56 significant at the $1 \%$ level. The estimated parameters were then applied to each observation to determine the residual contribution of firm size (SIZE_RESID), calculated as follows: SIZE_RESID $=S I Z E-10.565-0.395 *\left(B O A R D \_S I Z E\right)$

${ }^{4}$ The application of the simultaneous equations model requires compliance with two conditions (verified in our case): one so-called order condition and another called rank condition.
} 
on the market is likely to conceal the use of surplus discretionary funds. These results are consistent with those found by Chung et al. (2005a), Jaggi and Gul (2006) and Bukit and Iskandar (2009).

Table 2. Results of Three Stage Least Square Simultaneous (3SLS) Models

\begin{tabular}{|c|c|c|c|c|c|c|c|c|}
\hline & \multicolumn{2}{|c|}{$\begin{array}{c}\text { Overall Sample } \\
(\text { Nb. Obs. }=789)\end{array}$} & \multicolumn{2}{|c|}{$\begin{array}{l}\text { Upward Earnings } \\
\text { Management } \\
\text { (DAC_UP) } \\
\text { (Nb. Obs. }=196)\end{array}$} & \multicolumn{2}{|c|}{$\begin{array}{c}\text { Downward Earnings } \\
\text { Management } \\
\text { (DAC_DOW) } \\
(\text { Nb. Obs. }=201) \\
\end{array}$} & \multicolumn{2}{|c|}{$\begin{array}{c}\text { Moderate Earnings } \\
\text { Management } \\
\text { (DAC_MOD) } \\
\text { (Nb. Obs. }=\text { 392) }\end{array}$} \\
\hline & DAC & FCF & DAC & FCF & DAC & FCF & DAC & FCF \\
\hline FCF & $\begin{array}{l}0.641^{* * *} \\
(3.19)\end{array}$ & & $\begin{array}{l}0.969^{* *} \\
(2.54) \\
\end{array}$ & & $\begin{array}{c}0.024 \\
(0.12) \\
\end{array}$ & & $\begin{array}{l}-0.077^{* *} \\
(-2.26)\end{array}$ & \\
\hline BOARD_SIZE & $\begin{array}{c}0.003^{* *} \\
(1.97)\end{array}$ & $\begin{array}{c}-0.002^{*} \\
(-1.87)\end{array}$ & $\begin{array}{c}-0.005 \\
(-0.95)\end{array}$ & $\begin{array}{c}0.006^{*} \\
(1.73)\end{array}$ & $\begin{array}{c}-0.002 \\
(-1.33)\end{array}$ & $\begin{array}{l}-0.003^{* *} \\
(-2.34)\end{array}$ & $\begin{array}{l}0.001^{* * *} \\
(2.67)\end{array}$ & $\begin{array}{c}-0.000 \\
(-0.11)\end{array}$ \\
\hline BOARD_IND & $\begin{array}{r}0.024 \\
(0.85) \\
\end{array}$ & $\begin{array}{r}-0.027 \\
(-1.47) \\
\end{array}$ & $\begin{array}{r}0.005 \\
(0.07) \\
\end{array}$ & $\begin{array}{c}-0.032 \\
(-0.63) \\
\end{array}$ & $\begin{array}{c}0.000 \\
(0.00) \\
\end{array}$ & $\begin{array}{r}0.015 \\
(0.70)\end{array}$ & $\begin{array}{c}0.002 \\
(0.31) \\
\end{array}$ & $\begin{array}{c}-0.017 \\
(-1.16) \\
\end{array}$ \\
\hline DUAL & $\begin{array}{l}0.036^{* * *} \\
(2.80) \\
\end{array}$ & $\begin{array}{l}0.019^{* *} \\
(2.29) \\
\end{array}$ & $\begin{array}{l}-0.014 \\
(-0.42) \\
\end{array}$ & $\begin{array}{l}-0.012 \\
(-0.54) \\
\end{array}$ & $\begin{array}{c}0.013 \\
(0.85) \\
\end{array}$ & $\begin{array}{l}0.033^{* * *} \\
(2.85)\end{array}$ & $\begin{array}{l}-0.001 \\
(-0.39) \\
\end{array}$ & $\begin{array}{l}-0.003 \\
(-0.50) \\
\end{array}$ \\
\hline IND_OWN & $\begin{array}{r}0.052 \\
(1.49) \\
\end{array}$ & $\begin{array}{l}-0.016 \\
(-0.72) \\
\end{array}$ & $\begin{array}{c}0.113 \\
(1.03) \\
\end{array}$ & $\begin{array}{c}-0.042 \\
(-0.60) \\
\end{array}$ & $\begin{array}{c}-0.033 \\
(-0.78) \\
\end{array}$ & $\begin{array}{l}-0.088^{* * *} \\
(-2.88)\end{array}$ & $\begin{array}{c}-0.012 \\
(-1.53) \\
\end{array}$ & $\begin{array}{c}0.009 \\
(0.52) \\
\end{array}$ \\
\hline AUDICOM & $\begin{array}{r}0.017 \\
(1.01) \\
\end{array}$ & $\begin{array}{r}-0.017 \\
(-1.54) \\
\end{array}$ & $\begin{array}{c}-0.019 \\
(-0.46) \\
\end{array}$ & $\begin{array}{c}0.001 \\
(0.06) \\
\end{array}$ & $\begin{array}{c}-0.001 \\
(-0.07) \\
\end{array}$ & $\begin{array}{c}0.010 \\
(0.64) \\
\end{array}$ & $\begin{array}{c}0.006 \\
(1.49) \\
\end{array}$ & $\begin{array}{c}-0.008 \\
(-0.91) \\
\end{array}$ \\
\hline AUDICOM_IND & $\begin{array}{l}-0.047^{* *} \\
(-2.19)\end{array}$ & $\begin{array}{l}0.028^{* *} \\
(2.04)\end{array}$ & $\begin{array}{c}0.071 \\
(1.13) \\
\end{array}$ & $\begin{array}{l}-0.035 \\
(-0.95)\end{array}$ & $\begin{array}{c}0.023 \\
(0.98) \\
\end{array}$ & $\begin{array}{r}0.017 \\
(0.94) \\
\end{array}$ & $\begin{array}{l}-0.004 \\
(-0.85) \\
\end{array}$ & $\begin{array}{l}-0.006 \\
(-0.56)\end{array}$ \\
\hline REF_SHARE & $\begin{array}{c}-0.024 \\
(-0.69) \\
\end{array}$ & $\begin{array}{l}-0.005 \\
(-0.25) \\
\end{array}$ & $\begin{array}{c}-0.191^{*} \\
(-1.81)\end{array}$ & $\begin{array}{c}0.067 \\
(1.02) \\
\end{array}$ & $\begin{array}{c}0.088^{* *} \\
(2.07)\end{array}$ & $\begin{array}{r}0.017 \\
(0.54) \\
\end{array}$ & $\begin{array}{l}0.027^{* * *} \\
(2.96)\end{array}$ & $\begin{array}{c}-0.020 \\
(-1.07) \\
\end{array}$ \\
\hline INST_OWN & $\begin{array}{c}0.015 \\
(0.43)\end{array}$ & $\begin{array}{c}0.031 \\
(1.34)\end{array}$ & $\begin{array}{c}0.001 \\
(0.01)\end{array}$ & $\begin{array}{c}0.066 \\
(0.92)\end{array}$ & $\begin{array}{l}-0.094^{* *} \\
(-2.55)\end{array}$ & $\begin{array}{c}0.010 \\
(0.34)\end{array}$ & $\begin{array}{l}-0.012 \\
(-1.48)\end{array}$ & $\begin{array}{l}-0.040^{* *} \\
(-2.19)\end{array}$ \\
\hline MAN_OWN & $\begin{array}{l}-0.088^{* *} \\
(-2.21)\end{array}$ & $\begin{array}{l}0.077^{* * *} \\
(3.29)\end{array}$ & $\begin{array}{l}-0.188^{*} \\
(-1.70)\end{array}$ & $\begin{array}{l}0.180^{* * *} \\
(3.20)\end{array}$ & $\begin{array}{l}-0.082^{\text {** }} \\
(-2.05)\end{array}$ & $\begin{array}{l}-0.043 \\
(-1.30)\end{array}$ & $\begin{array}{l}-0.008 \\
(-0.87) \\
\end{array}$ & $\begin{array}{c}0.022 \\
(1.07)\end{array}$ \\
\hline BIG & $\begin{array}{l}-0.008 \\
(-1.26) \\
\end{array}$ & & $\begin{array}{c}-1.70 \\
(-1.21) \\
\end{array}$ & & $\begin{array}{l}-0.003 \\
(-0.31) \\
\end{array}$ & & $\begin{array}{l}0.005^{* *} \\
(2.41) \\
\end{array}$ & \\
\hline DEBT & $\begin{array}{l}0.149^{* * *} \\
(2.60) \\
\end{array}$ & $\begin{array}{l}-0.195^{* * *} \\
(-5.72)\end{array}$ & $\begin{array}{c}0.139 \\
(0.99) \\
\end{array}$ & $\begin{array}{c}-0.118 \\
(-1.29) \\
\end{array}$ & $\begin{array}{c}-0.090^{*} \\
(-1.82) \\
\end{array}$ & $\begin{array}{c}-0.055 \\
(-1.30) \\
\end{array}$ & $\begin{array}{c}0.002 \\
(0.20) \\
\end{array}$ & $\begin{array}{l}-0.166^{* * *} \\
(-5.62)\end{array}$ \\
\hline CROSS_LIST & $\begin{array}{c}-0.018 \\
(-1.56) \\
\end{array}$ & & $\begin{array}{c}-0.052^{*} \\
(-1.71) \\
\end{array}$ & & $\begin{array}{c}0.012 \\
(0.63) \\
\end{array}$ & & $\begin{array}{l}-0.000 \\
(-0.11) \\
\end{array}$ & \\
\hline IFRS & $\begin{array}{l}-0.031^{* *} \\
(-2.55)\end{array}$ & $\begin{array}{l}0.020^{* * *} \\
(2.77)\end{array}$ & $\begin{array}{l}-0.083^{* *} \\
(-2.16)\end{array}$ & $\begin{array}{l}0.051^{* *} \\
(2.38)\end{array}$ & $\begin{array}{r}0.016 \\
(1.49) \\
\end{array}$ & $\begin{array}{l}-0.017^{*} \\
(-1.88)\end{array}$ & $\begin{array}{l}-0.008^{* * *} \\
(-3.05)\end{array}$ & $\begin{array}{c}0.005 \\
(0.93) \\
\end{array}$ \\
\hline DIV & & $\begin{array}{l}0.001^{* *} \\
(2.48)\end{array}$ & & $\begin{array}{c}0.001 \\
(0.79) \\
\end{array}$ & & $\begin{array}{c}0.002^{*} \\
(1.65)\end{array}$ & & $\begin{array}{l}0.004^{* * *} \\
(5.60)\end{array}$ \\
\hline ROA & & $\begin{array}{l}-0.870^{* * *} \\
(-7.72)\end{array}$ & & $\begin{array}{l}-0.856^{* * *} \\
(-4.02) \\
\end{array}$ & & $\begin{array}{l}-0.963^{* * *} \\
(-5.34) \\
\end{array}$ & & $\begin{array}{l}-1.305^{* * *} \\
(-11.70) \\
\end{array}$ \\
\hline SIZE_RESID & $\begin{array}{l}-0.110^{*} \\
(-1.82)\end{array}$ & $\begin{array}{c}0.001 \\
(0.32) \\
\end{array}$ & $\begin{array}{c}-0.081 \\
(-1.57) \\
\end{array}$ & $\begin{array}{c}0.001 \\
(0.04) \\
\end{array}$ & $\begin{array}{l}-0.046^{* * *} \\
(-2.60)\end{array}$ & $\begin{array}{c}0.043 \\
(1.33) \\
\end{array}$ & $\begin{array}{l}-0.043^{* * *} \\
(-2.97)\end{array}$ & $\begin{array}{c}0.005 \\
(0.41)\end{array}$ \\
\hline Intercept & $\begin{array}{l}-0.104 \\
(-1.37) \\
\end{array}$ & $\begin{array}{l}0.157^{* * *} \\
(3.99)\end{array}$ & $\begin{array}{l}-0.048 \\
(-0.24)\end{array}$ & $\begin{array}{r}0.015 \\
(0.11) \\
\end{array}$ & $\begin{array}{l}0.187^{* * *} \\
(3.51)\end{array}$ & $\begin{array}{l}0.104^{* *} \\
(2.51)\end{array}$ & $\begin{array}{l}-0.002 \\
(-0.17)\end{array}$ & $\begin{array}{l}0.184^{\text {*** }} \\
(5.13)\end{array}$ \\
\hline $\begin{array}{l}\text { INDUSTRY } \\
\text { YEAR } \\
\text { R-squared } \\
\end{array}$ & $\begin{array}{c}\text { Yes } \\
\text { Yes } \\
51.71 \% \\
\end{array}$ & $\begin{array}{c}\text { Yes } \\
\text { Yes } \\
28.70 \% \\
\end{array}$ & $\begin{array}{c}\text { Yes } \\
\text { Yes } \\
71.53 \% \\
\end{array}$ & $\begin{array}{c}\text { Yes } \\
\text { Yes } \\
43.91 \% \\
\end{array}$ & $\begin{array}{c}\text { Yes } \\
\text { Yes } \\
24.53 \%\end{array}$ & $\begin{array}{c}\text { Yes } \\
\text { Yes } \\
42.48 \%\end{array}$ & $\begin{array}{c}\text { Yes } \\
\text { Yes } \\
24.68 \%\end{array}$ & $\begin{array}{c}\text { Yes } \\
\text { Yes } \\
49.05 \%\end{array}$ \\
\hline
\end{tabular}

${ }^{* * *}$ and ${ }^{* * *}$ indicate significance at the 10,5 and $1 \%$ levels, respectively.

Among the characteristics of the board, our results show that the size of the board (BOARD_SIZE) and CEO duality $(D U A L)$ positively and significantly affect earnings management in a $F C F$ situation, at the $5 \%$ and $1 \%$ levels, respectively. Consistent with our H2a, a relatively large-sized board may have a negative impact on the production of financial statements in conformity with accounting principles. CEO duality, limiting control of executives, is likely to increase the agency costs related to the $F C F$ problem and encourage executives to use discretionary accruals. This result is consistent with Lasfer's (2006) in the British context and thus validates our hypothesis H3. The positive relation between DUAL and FCF variables is consistent with related studies in the French context. 
Indeed, Boubaker et al. (2013) find that companies splitting CEO and chair positions are less likely to accumulate cash reserves than those with CEO duality.

The percentage of independent directors on the board (BOARD_IND) and their participation in the capital $\left(I N D \_O W N\right)$ do not seem to exert a significant influence over earnings management nor at aggregate sample or at studied sub-samples levels. Hypotheses H2b and $\mathrm{H} 9$ are therefore rejected.

Regarding the characteristics of the audit committee, for the whole sample, Table 2 shows that audit committee independent (AUDCOM_IND) has a negative impact on earnings management. Consistent with our fourth hypothesis, this feature limits executives' opportunistic behavior in accounting manipulations, in a FCF situation. This finding is consistent with the result of Bukit and Iskander (2009) in the case of Malaysian companies suggesting that the independence of the audit committee members can limit earnings management practices, mainly in companies with a FCF problem.

With respect to ownership characteristics at overall sample level, the results show that the percentage of voting rights held by the reference shareholder ( $\left.R E F_{-} S H A R E\right)$ has no significant impact on earnings management. For companies that manage their earnings upwards, the impact is negative $(-0.191)$ and significant at $10 \%$ level. Contrasting results, however, are found in companies that manage their earnings downwards $(0.088)$ or at a moderate manner (0.027). These results are significant at $5 \%$ and $1 \%$ levels respectively and do not support Dechow et al. (1996) and Attig et al.'s (2013) findings that controlling shareholder ownership is an effective monitoring mechanism. Conversely, they can encourage corporate executives to make accounting manipulations likely to facilitate the extraction of private benefits. This is particularly observed in countries such as France, offering little protection to minority shareholders (Nekhili and Cherif, 2011). For firms that manage their earnings downward, our results show that institutional ownership (INST_OWN) has a negative $(-0.094)$ and significant effect at the 5\% level on earnings management. Institutional ownership can limit management earnings in a $F C F$ situation. This result justifies institutional investors' activism and their role as key players in corporate governance structures, emphasizing control and limiting executives' discretionary power.

Table 2 also shows a positive relation between the percentage of capital held by managers and $F C F$ level. This result is significant for overall sample and for sub-samples of companies that manage their earnings up. However, in accordance with Warfield et al.'s results (1995), managerial ownership $\left(M A N \_O W N\right)$ has a negative and significant effect on earnings management. This result was observed both in the overall sample $(-0.088)$ at the level of subsamples of companies that manage their earnings up $(-0.188)$ or downward $(-0.082)$. Thus, in accordance with the agency theory by Jensen and Meckling (1976), earnings management practices are limited as the percentage of capital held by executives is high. Our hypothesis H8 is then accepted.

With respect to companies that manage their earnings in a moderate way, Table 2 shows that the size of the external auditor has a positive, but very low, and significant impact on earnings management $(0.005$ at the $5 \%$ level). This finding contradicts Chung et al. (2005a) and Rusmin et al. (2014) who find that "Big" auditors limit the use of discretionary accruals especially when corporate clients have a high $F C F$ level. ${ }^{5}$ We therefore reject our fifth hypothesis. Our result confirms, however, Francis et al.'s (2009) findings. These authors argue that companies that publish relatively average discretionary accruals levels are those that rely more on "Big" auditors.

For control variables, the coefficient related to listing in the United States stock market (CROSS_LIST) is significantly negative at the $10 \%$ level for the sub-sample of companies that manage their earnings upward. Such a result shows that listing on the U.S. market forces the company to comply with the requirements of this market and with often more stringent disclosure rules than those of the domestic market, and thus make poor use of $F C F$ more expensive (Doidge et al. 2004). Moreover, the adoption of IFRS has a positive effect on the production of better accounting results. The adoption of IFRS standards provides an environment conducive to the production and publication of better quality accounting results. At overall sample level, we find a positive and significant relation at

\footnotetext{
${ }^{5}$ The univariate analysis of Rusmin et al. (2014) shows that Big 4 accounting firms have significantly lower discretionary accruals compared to that of in Non-Big 4 audited firms. However, In their multivariate analysis, audit quality impacts significantly earning management practices only in Malaysia and this result is insignificant in Singapore and Indonesia.
} 
the $1 \%$ level between debt and discretionary accruals. Henceforth, the use of debt cannot be considered as having any disciplinary effect on managers. Our result is consistent with Jones and Sharma (2001) findings that lower leverage is associated with higher earnings management. More importantly, the authors suggest that leverage does have positive association with earnings management when combined with free cash flows. Surprisingly, we find a positive and significant relationship between the dividend yield and the level of $F C F$, on one hand, and a negative and significant relationship between $R O A$ and $F C F$. Taken together, these results suggest that managers do not take advantage of the current profits to accumulate cash and use dividends to convey positive information to investors in $F C F$ situation. Finally, we find that larger firms are less likely to use discretionary accruals to manage their earnings levels.

\section{CONCLUSION}

The aim of this paper is to study the relation between $F C F$ and earnings management. In particular, it tests whether earnings are upwardly or downwardly managed in the presence of the $F C F$. Using a sample of 85 French listed companies belonging to the SBF 120 during the period 2001-2010, the results show that companies with high $F C F$ are more inclined to upwardly manage their earnings. They also show that, in the presence of $F C F$, the propensity of corporate executives to use discretionary accruals depends on the firm ownership and the effectiveness of governance mechanisms. More specifically, audit committee independence and external audit quality along with firm ownership structure (such as institutional investors and managerial ownership) reduce the extent of earnings management in the presence of free cash flows. However, board independence and independent directors' ownership has no significant impact on earnings management suggesting that corporate governance mechanisms are substitutive in their monitoring role to reduce earnings management in a free cash flow situation. On the basis of these results, our research may have relevant implications for investors, reformers, regulators and governance experts who prerequisite understandings about related category of agency problems that may arise in French context.

\section{AUTHOR BIOGRAPHIES}

Mehdi Nekhili holds a PhD degree from the University of Burgundy in France. He is now a Professor of Finance at University of Maine (France) and an Affiliated Professor at ICD International Business School (France). His main research interests include accounting, auditing, banking and corporate governance. He has published several papers in various refereed journals such as Journal of Business Ethics, Auditing: Journal of Practice and Theory, Journal of Applied Business Research, Managerial Auditing Journal and Review of Accounting and Finance and many chapters in books. He has also edited a book entitled "International Banking Strategies". Email: mehdi.nekhili@univ-reims.fr

Ines Fakhfakh Ben Amar holds a PhD degree from the University of Reims in France. She is now an Assistant Professor in Accountant and financial methods at the University of Sfax (Tunisia) in the Higher Institute of Business Administration (Tunisia). His main research interests include theory accounting, auditing, business finance and corporate governance. She has participated in several international congress and conferences. She has also published some papers in the areas of research already mentioned.Email : fakhfakh_ines@yahoo.fr

Tawhid Chtioui holds a PhD in the University of Paris Dauphine Management Science and Leadership Development Program in Higher Education at the Harvard Graduate School of Education. Author of several scientific articles, he has taught at several schools and universities in France and abroad and has held scientific and management positions in various business schools. He is serial entrepreneur and has held consulting and corporate training activities. Email: tchtioui@groupe-igs.fr

Faten Lakhal is $\mathrm{PhD}$ and a professor in accounting at the University of Sousse (Tunisia) and a fellow researcher at the IRG (Institut de Recherche en Gestion) at Paris-Est University (France). Her major publications include the Journal of Accounting and Finance, Bankers, Markets and Investors, the International Journal of Business, the Managerial Auditing Journal among others. Her special research interests are in corporate governance, gender diversity, corporate disclosure and earnings quality. Email: lakhal@u-pec.fr 


\section{REFERENCES}

Agrawal, A. and Jayaraman, N. (1994). The dividend policies of all-equity firms: A direct test of the free cash flow theory. Managerial and Decision Economics, 15 (2) 139-148.

Alonso, P. D. A., Iturriaga, F. J. L. and Sanz, J. A. R. (2005). Financial decisions and growth opportunities: A Spanish firms panel data analysis. Applied Financial Economics, 15 (6) 391-407.

Attig, N., El Ghoul, S. Guedhami, O. and Riseanu, S. (2013). The governance role of multiple large shareholders: Evidence on the valuation of cash holdings. Journal of Management and Governance, 17 (2) 419-451.

Beasley, M. S. (1996). An empirical analysis of the relation between the board of director composition and financial statement fraud. The Accounting Review, 71 (4) 443-465.

Boubaker, S., Derouiche, I. and Nguyen, D. K. (2013). Does the board of directors affect cash holdings? A study of French listed firms. Journal of Management \& Governance, 19 (2) 341-370.

Bukit, R. and Iskandar, T. M. (2009). Surplus free cash flow, earnings management and audit committee. International Journal of Economics and Management, 3 (1) 204-223.

Bradbury, M. E. (1990). The incentives for voluntary audit committee formation. Journal of Accounting and Public Policy, 9 (1) 19-36.

Cheng, Z., Cullinan, C. P. and Zhang, J. (2014). Free Cash Flow, Growth Opportunities, And Dividends: Does Cross-Listing Of Shares Matter? Journal of Applied Business Research, 30 (2) 587-598.

Chung, R., Firth, M. and Kim J. B. (2005a). Earnings management, surplus free cash flow, and external monitoring. Journal of Business Research, 58 (6) 766-776.

Chung, R., Firth, M. and Kim, J. B. (2005b). FCF agency costs, earnings management and investor monitoring", Corporate Ownership and Control, 2 (4) 51-61.

DeAngelo, L. (1981). Auditor size and audit quality. Journal of Accounting and Economics, 3 (3) 183-199.

Dechow, P., Sloan, R. and Sweeney, A. (1996). Causes and consequences of earnings manipulation and analysis of firms subject to enforcement by the SEC. Contemporary Accounting Research, 13 (1) 1-36.

Denis, D. J. and Denis, D. K. (1995). Performance changes following top management dismissals. Journal of Finance, 50 (4) 1029-1057.

Denis, D. J., Denis, D. K. and Sarin, A. (1994). The information content of dividend changes: Cash flow signalling, overinvestment, and dividend clienteles. Journal of Financial and Quantitative Analysis, 29 (4) 567-587.

Dittmar, A., Mahrt-Smith, J. and Servaes, H. (2003). International corporate governance and corporate cash holdings. Journal of Financial and Quantitative Analysis, 38 (1) 111-133.

Doidge, C., Karolyi, G. A. and Stulz, R. M. (2004). Why are foreign firms listed in the U.S. worth more? Journal of Financial Economics, 71 (2) 205-238.

Francis, J. R., Richard, C. and Vanstraelen, A. (2009). Assessing France's joint audit requirement: are two heads better than one? Auditing: A Journal of Practice and Theory, 28 (2) 35-63.

Francis, J. R. and Wang, D. (2008). The joint effect of investor protection and Big Four audits on earnings quality around the world. Contemporary Accounting Research, 25 (1) 157-191.

Gregory, A. and Wang, Y-H. (2013). Cash acquirers: Can free cash flow, debt and institutional ownership explain long-run performance? Review of Behavioral Finance, 5 (1) 35-57.

Gugler, K. (2003). Corporate governance, payout policy and the interrelation between dividends, R\&D, and capital investment. Journal of Banking and Finance, 27 (7) 1297-1321.

Gul, F. A. and Tsui, J. (1998). A test of the free cash flow and debt monitoring hypotheses: Evidence from audit pricing. Journal of Accounting and Economics, 24 (2) 219-237.

Hribar, P. and Collins, D. W. (2002). Errors in estimating accruals: Implications for empirical research. Journal of Accounting Research, 40 (1) 105-134.

Iskandar-Datta, M. E. and Jia, Y. (2012). Cross-country analysis of secular cash trends. Journal of Banking \& Finance, 36 (3) 898-912.

Jaggi, B. and Gul, F. A. (2006). Evidence of accruals management: A test of the free cash flow and debt monitoring hypotheses. working paper, http://ssrn.com/abstract $=2699$.

Jaggi, B. and Gul, F. A. (1999). An analysis of joint effects of investment opportunity set, free cash flows and size on corporate debt policy. Review of Quantitative Finance and Accounting, 12 (4) 371-381.

Jeanjean, T. and Stolowy, H. (2008). Do accounting standards matter? An exploratory analysis of earnings management before and after IFRS adoption. Journal of Accounting and Public Policy, 27 (6) 480-494.

Jelinek, K. (2007). The effect of leverage increases on earnings management. Journal of Business and Economic Studies, 13 (2) 24-46.

Jensen, M. C. (1986). Agency costs of the free cash flow, corporate finance and takeovers. American Economic Review, 76 (2) $323-329$.

Jensen, M. C. and Meckling, W. (1976). Theory of the firm: Managerial behavior, agency costs and ownership structure. Journal of Financial Economics, 3 (4) 305-360. 
Jensen, M. C. and Murphy, K. J. (1990). Performance pay and top-management incentives. Journal of Political Economy, 98 225-264.

Jones, S. and Sharma, R. (2001). The impact of free cash flow, financial leverage and accounting regulation on earnings management in Australia's "old" and "new" economies. Managerial Finance, 27 (12) 18-39.

Klapper, L. F. and Love, I. (2004). Corporate governance, investor protection and performance in emerging markets. Journal of Corporate Finance, 10 (5) 703-728.

Kothari, S. P., Leone, A. L. and Wasley, C. E. (2005). Performance matched discretionary accruals. Journal of Accounting and Economics, 39 (1) 23-49.

Lang, L. H. P. and Litzenberger, R. H., (1989). Dividend announcement, cash flow signalling vs free cash flow hypothesis? Journal of Financial Economics, 24 (1) 181-191.

Lang, L. H. P. Ofek, E., \& Stulz, R (1996). Leverage, investment, and firm growth. Journal of Financial Economics, 40 (1) 3-29.

Lasfer, M. A. (2006). The inter-relationship between managerial ownership and board structure. Journal of Business Finance and Accounting, 33 (7-8) 1006-1033.

Lehn, K. and Poulsen, A. (1989). Free cash flow and stockholder gains in going private transactions. Journal of Finance, 44 (3) 771-787.

Leuz, C., Nanda D. and Wysocki, P. D. (2003). Earnings management and investor protection: an international comparison. Journal of Financial Economics, 69 (3) 505-527.

Lipton, M. and Lorsch, J. (1992). A modest proposal for improved corporate governance. Business Lawyer, 48 (1) 59-77.

McConnell, J. and Servaes, H. (1995). Equity ownership and two faces of debt. Journal of Financial Economics, 39 (1) $131-157$.

Miguel, A. and Pindado, J. (2001). Determinants of capital structure: New evidence from Spanish panel data. Journal of Corporate Finance, 7 (1) 77-99.

Nekhili, M, and Cherif, M. (2011). Related parties' transactions and firm's market value: The French case. Review of Accounting and Finance, 10 (3) 291-315.

Nekhili, M. Siala Wali, A., and Chebbi Nekhili, D. (2009). Free-cash-flow, gouvernance et politique financière des entreprises françaises. Finance Contrôle Stratégie, 12 (1) 5-31.

Opler, T., Pinkowitz, L., Stulz, R. and Williamson, R. (1999). The determinants and implications of corporate cash holdings. Journal of Financial Economics, 52 (1) 3-46.

Peasnell, K. V., Pope, P. F. and Young, S. (2005). Board monitoring and earnings management: Do outside directors influence abnormal accruals? Journal of Business Finance and Accounting, 32 (7-8) 1311-1346.

Pindado, J. and De la Torre, C. (2009). Effect of ownership structure on underinvestment and overinvestment: Empirical evidence from Spain. Accounting and Finance, 49 (2) 363-383.

Piot, C. and Janin, R. (2007). External auditors, audit committees and earnings management in France. European Accounting Review, 16 (2) 429-454.

Richardson, S. (2006). Over-investment of free cash flow and corporate governance. Review of Accounting Studies, 11 (2-3) 159189.

Rusmin, R., Astami, E. W. and Hartadi, B. (2014). The impact of surplus free cash flow and audit quality on earnings management: The case of growth triangle countries. Asian Review of Accounting, 22 (3) 217-232.

Smith, J. and Watts, R. L. (1992). The investment opportunity set and corporate financing, dividend and compensation policies. Journal of Financial Economics, 32 (3) 263-292.

Stulz, R. (1990). Managerial discretion and optimal financing policies. Journal of Financial Economics, 26 (1) 3-27.

Warfield, T. D., Wild, J. J. and Wild, K. L. (1995). Managerial ownership, accounting choices, and informativeness of earnings. Journal of Accounting and Economics, 20 (1) 61-91. 